\title{
PENGARUH PEMBERIAN JINTAN HITAM (Nigella sativa) TERHADAP KADAR HDL (HIGH DENSITY LIPOPROTEIN) DAN LDL (LOW DENSITY LIPOPROTEIN) PADA BROILER JANTAN
}

\author{
The Influence of Black cumin (Nigella sativa) on HDL (High Density Lipoprotein) and LDL (Low \\ Density Lipoprotein) Levels in Male Broiler Chickens
}

\author{
Syahroni, Purnama Edy Santosa, Siswanto, dan Madi Hartono \\ Department of Animal Husbandry, Faculty of Agriculture Lampung University \\ Soemantri Brojonegoro No. 1 Gedong Meneng Bandar Lampung 35145 \\ e-mail: syahroniali12@gmail.com
}

\begin{abstract}
These study aimed to determine the effectiveness of Nigella sativa in increasing HDL levels and reducing LDL levels in male broilers. This research was conducted in December 2019 - January 2020 at the Integrated Field Laboratory, Faculty of Agriculture, University of Lampung. Analysis of HDL and LDL levels was carried out in Pramitra Biolab Indonesia. The study used sixty blood samples of Cobb male broiler. This study used a completely randomized design (CRD) with four treatments and each treatment was repeated three times, namely drinking water without a mixture of Nigella sativa (P0), drinking water with $36 \mathrm{mg} / \mathrm{kg}$ body weight=BW/day Nigella sativa (P1), drinking water with $72 \mathrm{mg} / \mathrm{kg}$ BW/day Nigella sativa (P2), drinking water with $144 \mathrm{mg} / \mathrm{kg}$ BW/day Nigella sativa (P3). Based on descriptive analysis that has been done Nigella sativa was effective in increasing HDL levels and reducing LDL levels in male broilers. Giving Nigella sativa with dose of $72 \mathrm{mg} / \mathrm{kg}$ BW/day resulted in the highest HDL levels of 88.6 $\mathrm{mg} / \mathrm{dl}$, whereas administration of Nigella sativa with dose of $144 \mathrm{mg} / \mathrm{kg} \mathrm{BW} /$ day resulted in the lowest LDL level of $31.3 \mathrm{mg} / \mathrm{dl}$.
\end{abstract}

Keywords: HDL LDL, Male broiler chickens, Nigella sativa

\begin{abstract}
ABSTRAK
Penelitian ini bertujuan untuk mengetahui efektifitas Nigella sativa dalam meningkatkan kadar HDL dan menurunkan kadar LDL pada broiler jantan. Penelitian dilaksanakan pada Desember 2019--Januari 2020 di Laboratorium Lapang Terpadu, Fakultas Pertanian, Universitas Lampung. Analisis kadar HDL dan LDL dilaksanakan di Pramitra Biolab Indonesia. Penelitian ini menggunakan 60 ekor broiler jantan. Penelitian ini menggunakan rancangan acak lengkap (RAL) dengan empat perlakuan dan setiap perlakuan diulang tiga kali yaitu air minum tanpa Nigella sativa (P0), air minum dengan $36 \mathrm{mg} / \mathrm{kg} \mathrm{BB} /$ hari Nigella sativa (P1), air minum dengan $72 \mathrm{mg} / \mathrm{kg} \mathrm{BB} /$ hariNigella sativa (P2), air minum dengan $144 \mathrm{mg} / \mathrm{kg} \mathrm{BB} / \mathrm{hari}$ Nigella sativa (P3). Pemberian Nigella sativa dengan dosis $72 \mathrm{mg} / \mathrm{kg} \mathrm{BB} / \mathrm{hari}$ menghasilkan kadar HDL tertinggi 88,6 mg/dl, sedangkan pemberian Nigella sativa dengan dosis $144 \mathrm{mg} / \mathrm{kg} \mathrm{BB} / \mathrm{hari}$ menghasilkan kadar LDL terendah yaitu $31,3 \mathrm{mg} / \mathrm{dl}$.
\end{abstract}

Kata kunci: Broiler Jantan, HDL, LDL, Nigella sativa

\section{PENDAHULUAN}

Penduduk Indonesia setiap tahunya terus meningkat. Menurut Bappenas (2019), penduduk Indonesia berjumlah 267 juta jiwa, dengan jumlah penduduk yang sedemikian tinggi, maka kebutuhan akan pangan akan semakin meningkat. Salah satu sumber pangan yang sangat penting adalah protein hewani. Sumber protein hewani berasal dari ternak, ikan, maupun sumber lainya.
Salah satu sumber protein hewani asal ternak yang banyak digemari yakni unggas.

Peternakan unggas terus berkembang, khususnya broiler. Meningkatnya peternakan broiler seiring dengan kesadaran masyarakat untuk mengkonsumsi protein hewani. Menurut BPS (2017), populasi broiler di Indonesia mencapai 1,69 miliar ekor. Menurut Murwani (2010), banyak faktor yang menyebabkan peternak menggemari broiler diantaranya pemeliharaanya mudah, pertambahan berat 
tubuhnya cepat, dan jangkauan pasarnya luas, tetapi disamping banyaknya keunggulan yang dimiliki, broiler juga memiliki kelemahan diantaranya adalah rentan terhadap penyakit.

Broiler sering juga menderita penyakit degeneratif yang dipicu oleh keadaan stres metabolik. Salah satu penyakit degenaratif yang menyerang broiler adalah aterosklerosis. Penyakit ini disebabkan oleh terhambatnya aliran oksigen dan makanan pada tubuh yang diakibatkan banyaknya LDL (low density lipoprotein) yang tidak dapat dibawa ke hati oleh HDL (high density lipoprotein), sehingga menempel pada dindingdinding pembuluh darah. Menurut Rawayulis (2008), hiperkolesterolemia adalah suatu keadaan terjadinya peningkatan kadar kolesterol di dalam darah.

Jintan Hitam (Nigella sativa) mengandung asam lemak jenuh dan phytosterol yang dapat meningkatkan kadar HDL dan menurunkan kadar LDL. Menurut Rolfes et al., (2006) lemak tidak jenuh yang dapat menurunkan trigliserida, kadar kolesterol total, VLDL (very low density lipoprotein) dan meningkatkan HDL. Selain itu, kandungan phytosterol menurunkan kadar kolesterol darah melalui kompetisi absorbsi di usus. Berdasarkan hal tersebut, peneliti menggunakan jintan hitam sebagai upaya meningkatkan kadar HDL dan menurunkan kadar LDL pada darah broiler, sehingga broiler akan terhindar dari penyakit degenerative.

\section{MATERI DAN METODE}

\section{Materi}

Alat-alat yang digunakan yaitu alat pemeliharaan, dispossable syringe, tabung SST (serum separator tube), peralatan pengujian kadar HDL dan LDL.

Bahan-bahan yang digunakan yaitu 60 ekor DOC broiler jantan $C o b b$, ransum broiler komersial novo 511, air minum, sediaan Nigella sativa, bahan untuk pengujian kadar HDL dan LDL yaitu reagen

\section{Rancangan Perlakuan}

Perlakuan diberikan ke broiler pada pagi hari berikutnya setelah DOC tiba (hari kedua). Penelitian dilakukan terhadap 60 sampel broiler jantan dengan empat perlakuan yaitu:

P0 : air minum tanpa campuran Nigella sativa

P1 : air minum dengan $36 \mathrm{mg} / \mathrm{kg}$ berat badan $=\mathrm{BB} /$ hari Nigella sativa;

P2 : air minum dengan $72 \mathrm{mg} / \mathrm{kg} \mathrm{BB} /$ hari Nigella sativa;
P3: air minum dengan $144 \mathrm{mg} / \mathrm{kg} \mathrm{BB} /$ hari Nigella sativa;

\section{Pelaksanaan Penelitian}

1. melakukan pemeliharaan 60 ekor DOC broiler jantan selama 30 hari;

2. melakukan program vaksinasi AI, IB, dan ND. Vaksin ND diberikan pada hari ke-6 melalui tetes mata dan hari ke-19 melalui air minum. Vaksin AI diberikan pada hari ke-6 melalui subkutan pada leher; sedangkan vaksin IB dilaksanakan pada hari ke 13 .

3. mengambil sampel darah menggunakan dispossable syringe melalui vena brachialis;

4. melakukan analisis kadar HDL dan LDL di Pramitra Biolab Indonesia

\section{Peubah yang diamati}

Peubah yang diamati pada penelitian ini adalah kadar HDL (high density lipoprotein) dan LDL (low density lipoprotein) pada broiler jantan dengan pemberian Nigella sativa dengan dosis yang berbeda

\section{Analisis data}

Data yang diperoleh dibuat dalam bentuk tabulasi sederhana, kemudian dibuat histogram dan dianalisis secara deskriptif.

\section{HASIL DAN PEMBAHASAN}

Pengaruh pemberian Jintan Hitam (Nigella sativa) terhadap kadar HDL pada broiler jantan

Rataan kadar HDL tertinggi terdapat pada P2 yaitu broiler yang diberi perlakuan 72 $\mathrm{mg} / \mathrm{kg} / \mathrm{bb} /$ hari dengan kadar HDL sebesar 88,6 $\mathrm{mg} / \mathrm{dl}$, sedangkan perlakuan lain cenderung lebih rendah jika dibandingkan $\mathrm{P} 2$ yaitu $\mathrm{P} 0, \mathrm{P} 1$, dan $\mathrm{P} 3$ yang masing-masing memiliki kadar HDL sebesar $67 \mathrm{mg} / \mathrm{dl}$, 62,3 mg/dl, dan 71,3 mg/dl. Rataan kadar HDL dapat dilihat pada Gambar 1 .

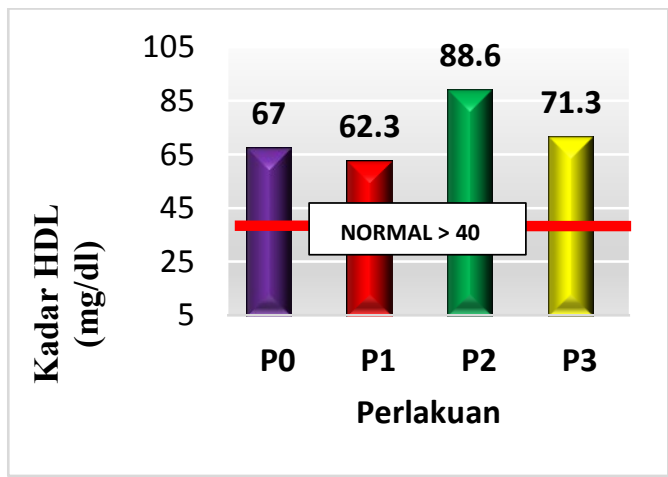

Gambar 1. Rataan kadar HDL pada penelitian 
Pada P1 broiler jantan yang diberi 36 $\mathrm{mg} / \mathrm{kg} / \mathrm{bb} / \mathrm{hari}$ Nigella sativa memiliki kadar HDL $62,3 \mathrm{mg} / \mathrm{dl}$ lebih rendah jika dibandingkan dengan serum darah broiler yang tidak diberi perlakuan yaitu sebesar $67 \mathrm{mg} / \mathrm{dl}$, dan jauh lebih rendah dibandingkan dengan $\mathrm{P} 2$ dan $\mathrm{P} 3$ yang masingmasing memiliki nilai $88,6 \mathrm{mg} / \mathrm{dl}$ dan $71,3 \mathrm{mg} / \mathrm{dl}$. Rendahnya kadar HDL pada perlakuan pertama diduga akibat dosis yang masih lebih rendah sehingga jumlah MUFA (mono unsaturated faty acid) yang diserap tubuh kurang optimal untuk meningkatkan kadar HDL, sehingga tidak berdampak pada kadar HDL pada P1.

Rendahnya kadar HDL pada perlakuan pertama diduga akibat dosis yang masih lebih rendah sehingga jumlah MUFA (mono unsaturated faty acid) yang diserap tubuh kurang optimal untuk meningkatkan kadar HDL. Menurut Rolfes et al., (2006), kandungan dari Nigella sativa adalah PUFA (poly unsaturated faty acid) dan MUFA PUFA (mono unsaturated faty acid) yang dapat menurunkan trigliserida, kadarkolesterol total, VLDL, dan meningkatkan HDL selain itu kandungan phytosterol menurunkan kadar kolesterol darah melalui kompetisi absorbsi di usus.

Pada P2 broiler jantan yang diberi $72 \mathrm{mg} / \mathrm{kg} / \mathrm{bb} / \mathrm{hari}$ Nigella sativa memiliki kadar HDL 88,6 mg/dl lebih tinggi jika dibandingkan dengan kadar HDL perlakuan lainya. Tingginya kadar HDL pada serum darah pada perlakuan kedua diduga diakibatkan dosis pada perlakuan yang tepat karena dosis tersebut merupakan dosis yang dianjurkan. Pada perlakuan ini kadar PUFA yang terserap ke dalam tubuh optimal sehingga akan merangsang hati untuk memproduksi lebih banyak HDL. Mekansisme kerja PUFA dalam menurunkan LDL dan meningkatkan kadar HDL sangat pelik, PUFA menginduksi ekspresi reseptor $\mathrm{X}$ hepar (liver X receptor; LXR) (Fernandez dan West, 2005).

Mekansisme kerja PUFA dalam menurunkan LDL dan meningkatkan kadar HDL sangat pelik, PUFA menginduksi ekspresi reseptor X hepar (liver $X$ receptor; LXR) (Fernandez dan West, 2005). Pada perlakuan P3 didapatkan kadar HDL sebesar 71,3 mg/dl lebih tinggi dari perlakuan satu dan kontrol, tetapi masih lebih rendah jika dibandingkan dengan perlakuan P2. Kurang optimalnya kadar HDL pada perlakuan $\mathrm{P} 3$ diduga akibat tingginya dosis yang diberikan sebesar $144 \mathrm{mg} / \mathrm{kg} / \mathrm{bb} /$ hari Nigella sativa. Dosis yang diberikan melebihi dosis yang disarankan sehingga kandungan asam lemak tak jenuh pada tubuh broiler berlebih, sehingga akan berdampak mengurangi efisiensi hati dalam memproduksi HDL.

Penurunan efisiensi kerja hati diduga diakibatkan oleh liver $x$ reseptor (LXR) yang secara berlebihan menginduksi ekspresi cholesterol 7a-hydroxylase (CYP7), sehingga kolestrol banyak yang dikonversi menjadi asam empedu. Hal ini sesuai pendapat Fernandez dan West (2005) LXR ini nantinya akan akan mengatur kadar kolesterol intraselular dengan menginduksi ekspresi cholesterol $7 \alpha$-hydroxylase (CYP7), enzim yang menginisiasi konversi kolesterol menjadi asam empedu.

Kadar HDL pada penelitian ini juga lebih tinggi jika dibandingkan dengan penelitian lainya. Hasil penelitian Setiawati et al., (2014) pada broiler yang diberi daun kiambang menghasilkan kadar HDL tertinggi sebesar $53,58 \mathrm{mg} / \mathrm{dl}$, hasil penelitian Bambang et al., (2005) pada ayam broiler yang diberi perlakuan pakan dengan serat kasar berbeda menghasilkan kadar HDL tertinggi sebesar $38,29 \mathrm{mg} / \mathrm{dl}$.

Efek Pemberian Jintan Hitam (Nigella sativa) terhadap kadar LDL pada broiler jantan

Rataan hasil pemeriksaan kadar LDL pada broiler jantan yang diberi perlakuan dengan pemberian Nigella sativa dapat dilihat pada Gambar 2.

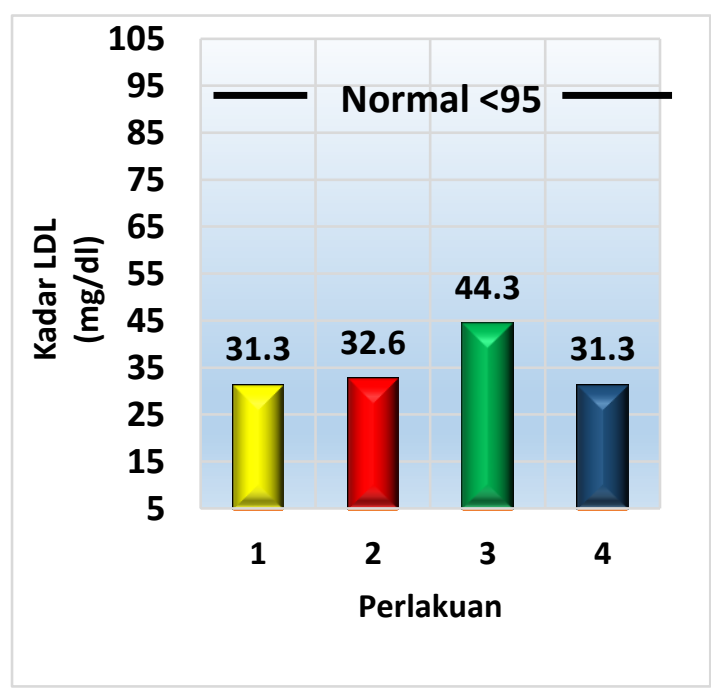

Gambar 2 rataan hasil uji kadar LDL

Rataan kadar LDL tertinggi terdapat pada perlakuan dua yaitu broiler yang diberi perlakuan $72 \mathrm{mg} / \mathrm{kg} / \mathrm{bb} /$ hari dengan kadar LDL sebesar 44,3 $\mathrm{mg} / \mathrm{dl}$, sedangkan perlakuan lain cenderung lebih rendah jika dibandingkan $\mathrm{P} 2$ yaitu $\mathrm{P} 0, \mathrm{P} 1$, dan $\mathrm{P} 3$ 
yang masing-masing memiliki kadar LDL sebesar $31,3 \mathrm{mg} / \mathrm{dl}$, 32,6 mg/dl, dan 31,3 mg/dl.

Pada perlakuan pertama broiler jantan yang diberi $36 \mathrm{mg} / \mathrm{kg} / \mathrm{bb} / \mathrm{hari}$ Nigella sativa memiliki kadar LDL 32,6 mg/dl lebih tinggi jika dibandingkan dengan serum darah broiler yang tidak diberi perlakuan dan yang diberi perlakuan dosis tertinggi yaitu sebesar $31,3 \mathrm{mg} / \mathrm{dl}$, dan jauh lebih rendah dibandingkan dengan P2 memiliki nilai 44,3 mg/d. Menurut Rolfes et al., (2006), kandungan dari Nigella sativa adalah PUFA yang dapat menurunkan trigliserida, kadar kolesterol total, VLDL, dan meningkatkan HDL selain itu kandungan phytosterol menurunkan kadar kolesterol darah melalui kompetisi absorbsi di usus.

Suryaatmaja dan Silman (2006) menjelaskan bahwa LDL mengirimkan kolesterol ke jaringan ekstra-hepatik, seperti sel korteks adrenal, ginjal, otot, dan limfosit. Sel tersebut mempunyai reseptor LDL di permukaannya. LDL melepaskan kolesterol di dalam sel untuk pembentukan hormon steroid dan sintesa dinding sel. Sel fagosit dari sistem retikuloendotel menangkap dan memecah LDL.

Pada perlakuan P2 broiler jantan yang diberi $72 \mathrm{mg} / \mathrm{kg} / \mathrm{bb} /$ hari Nigella sativa memiliki kadar LDL 44,3 mg/dl lebih tinggi jika dibandingkan dengan serum darah broiler pada P0, P1, dan P3. Tingginya kadar LDL pada P2 diduga karena belum optimalnya asam lemak tak jenuh dalam mengatur sterol, sehingga sterol tetap memproduksi kolestrol.

Menurut Fernandez dan West (2005), mekansisme kerja PUFA dalam menurunkan LDL sangat pelik, PUFA menginduksi ekspresi reseptor X hepar (liver X receptor; LXR), yaitu reseptor yang terdapat pada hepar sebagai sensor terhadap kadar sterol yang berfungsi membantu organisme mengatasi tingginya kadar kolesterol.

LXR ini nantinya akan akan mengatur kadar kolesterol intraselular dengan menginduksi ekspresi cholesterol 7a-hydroxylase (CYP7), enzim yang menginisiasi konversi kolesterol menjadi asam empedu.

Konversi kolesterol menjadi asam empedu bersifat irreversible dan merupakan proses akhir dari katabolisme kolesterol. Dengan demikian jumlah kolesterol yang digunakan untuk pembentukan VLDL akan berkurang dan akibatnya VLDL dan LDL yang terbentuk juga akan berkurang. Selain itu PUFA juga memiliki mekanisme peningkatan jumlah reseptor (up regulation) dari kolesterol LDL dan mengurangi konversi VLDL menjadi LDL sehingga nantinya peningkatan kadar kolesterol LDL dalam plasma dapat dicegah (Fernandez dan West, 2005).
Pada perlakuan P3 broiler jantan yang diberi $72 \mathrm{mg} / \mathrm{kg} \mathrm{BB} /$ hari Nigella sativa memiliki kadar LDL 31,3 mg/dl lebih rendah jika dibandingkan dengan serum darah broiler pada $\mathrm{P} 1$ dan P3 yang memiliki kadar LDL identik dengan serum broiler yang tidak diberi perlakuan. Rendahnya kadar LDL pada perlakuan ini diduga karena asam lemak tak jenuh berhasil dalam menjalankan fungsinya untuk menghambat pembentukan kolestrol dengan cara mengalihkan produksi kolestrol menjadi asam empedu. Setelah menjadi garam empedu bahan-bahan tersebut tidak lagi bisa digunakan untuk membuat kolestrol LDL.

Menurut Murray (2009), kandungan lemak jenuh tinggi membuat LDL mengambang di dalam darah. LDL dapat menyebabkan penempelan kolesterol di dinding pembuluh darah. LDL berfungsi membawa kolesterol dari hati menuju jaringan. Secara keseluruhan hasil uji kadar LDL pada penelitian menunjukan bahwasanya kadar LDL pada broiler normal karena lebih rendah jika dibandingkan dengan hasil penelitian Manoppo et al., (2007) melaporkan bahwa kadar LDL pada broiler berada pada kisaran 95--125 mg/dl.

Menurut Basmacioglu dan Ergul (2005), rata rata kadar LDL darah ayam ras adalah $<130$ $\mathrm{mg} / \mathrm{dl}$. Kadar LDL pada penelitian ini juga lebih rendah jika dibandingkan dengan penelitian lainya. Hasil penelitian Bambang et al., (2005) pada ayam broiler yang diberi perlakuan pakan dengan serat kasar berbeda menghasilkan kadar LDL sebesar $60 \mathrm{mg} / \mathrm{dl}$, sedangkan penelitian lain yang hasilnya mendekati penelitian dari Setiawati et al., (2014) pada broiler yang diberi daun kiambang menghasilkan kadar LDL sebesar $2^{7}$ $\mathrm{mg} / \mathrm{dl}$.

Berdasarkan hasil pengujian, kadar LDL terlihat normal dan cukup rendah, sehingga dapat terlihat bahwasanya broiler pada penelitian ini dalam kondisi yang baik. Kadar LDL yang r menjadikan broiler terhindar dari resiko te penyakit degeneratif seperti arteroklerosis. Menurut Soeharto (2004), arteroklerosis merupakan pengendapan plak yang berada di arteri karena banyaknya sisa-sisa metabolisme.

Terhindarnya broiler dari arteroklerosis diduga karena adanya kandungan thymoquinone pada jintan hitam. Menurut Al-Majed et al., (2006), jintan hitam mengandung volatile oil yang komponen utamanya adalah thymoquinone merupakan merupakan komponen utama dalam minyak esensial jintan hitam (50\%) dan termasuk dalam monetoprenoid keton dan bersifat antioksidan kuat. Antioksidan kuat yang ada pada thymoquinone dapat mencegah LDL teroksidasi oleh radikal bebas, sehingga LDL akan 
menjalankan fungsinya dengan baik dan tidak terurai dan menempel pada dinding pembuluh darah.

Arteroklerosis disebabkan oleh banyaknya sisa-sisa kolestrol LDL yang menyumbat pembuluh darah menyebabkan timbulnya plak dan pada akhirnya akan robek seiring dengan berjalanya waktu. Hal ini sesuai pendapat Guyton dan Hall (2012) yang menyatakan bahwa dinding plak akan mengalami degenerasi sehingga mudah sekali untuk robek. Pada robekan tersebut memungkinkan untuk trombosit menempel pada permukaan tersebut sehingga dapat membentuk suatu bekuan darah dan sewaktu-waktu dapat menyumbat aliran darah sehingga aliran darah dapat terhenti secara tiba-tiba.karena LDL dapat membawa sisa LDL dalam pembuluh darah menuju hati sehingga tidak terjadi penumpukan.

Rendahnya kolestrol LDL pada penelitian ini juga diduga karena kandungan phytosterol pada jintan hitam. Menurut Rolfes et al., (2006), jintan hitam juga mengandung alkaloid dan saponin, asam askorbat, asam dehidroaskorbat, lipase, phytosterol, betasitosterol, alphaspinasterol, stigmasterol, campesterol, dan tannin. Phytosterol merupakan senyawa yang mirip dengan kolestrol. Menurut Pateh et al., (2009), phytosterol adalah sterol nabati dengan struktur mirip kolesterol. Fitosterol terdiri dari 28 hingga 30 atom dengan steroid sebagai rangka struktur dengan gugus hidroksil menempel pada C-3 dari cincin $\mathrm{A}$, dan rantai alifatik pada atom $\mathrm{C}-17$ dari cincin D.

Kemiripan antara phytosterol dan kolestrol menyebabkan terjadi kompetisi absorbsi antara keduanya, sehingga jumlah kolestrol yang terserap akan berkurang. Berkurangnya kolestrol yang terserap akan menyebabkan berkurangnya kilomikron yang merupakan bahan baku pembuatan LDL. Menurut Krisnatuti dan Rina, (1999). kilomikron dibentuk dari triasilgliserol, kolesterol, protein dan berbagai lipid yang berasal dari makanan yang masuk usus halus. Hal ini sesuai pendapat Rolfes et al., (2006), phytosterol merupakan zat dari tumbuhan yang mempunyai struktur mirip kolesterol sehingga dapat menurunkan kadar kolesterol darah melalui kompetisi absorbsi di usus.

Suhu kandang yang tinggi diduga mengakibatkan rendahnya kadar LDL pada penelitian ini suhu kandang cukup tinggi, baik pada pagi, siang, maupun sore hari. Pada pagi hari rata-rata suhu mencapai $27,6{ }^{\circ} \mathrm{C}$. dengan suhu tertinggi pada pagi hari mencapai $29,6{ }^{\circ} \mathrm{C}$, sedangkan pada siang hari suhu tertinggi mencapai $34,4{ }^{\circ} \mathrm{C}$, dengan suhu terendah $29,4^{\circ} \mathrm{C}$, rata-rata suhu pada siang hari mencapai $31,3^{\circ} \mathrm{C}$, sedangkan pada sore hari suhu kandang masih terbilang cukup tinggi yaitu mencapai $32,8{ }^{\circ} \mathrm{C}$, dengan rata-rata suhu harian mencapai $30,3^{\circ} \mathrm{C}$.

Suhu kandang penelitian dapat dilihat pada tabel 4. Menurut Sugito et al., (2011), broiler merupakan ayam yang sangat rentan terhadap perubahan suhu lingkungan yang ekstrim. Broiler memiliki suhu dan kelembaban optimal untuk menunjang pertumbuhan yaitu berkisar, $20-25^{\circ} \mathrm{C}$ dan $50-70 \%$.

Kelembapan pada kandang penelitian ini cukup tinggi pada pagi, siang, dan sore hari. Pada siang hari kelembapan dapat mencapai $81 \%$. Kelembapan yang tinggi dapat menyebabkan ayam mengalami cekaman panas. Menurut Sugito et al., (2011), broiler merupakan ayam yang sangat rentan terhadap perubahan suhu lingkungan yang ekstrim.

Broiler memiliki suhu dan kelembaban optimal untuk menunjang pertumbuhan yaitu berkisar, $20-25^{\circ} \mathrm{C}$ dan $50-70 \%$. Menurut Rasyaf, (2011), ayam akan tumbuh optimal pada suhu lingkungana 19--21 ${ }^{\circ} \mathrm{C}$. Broiler berproduksi dengan baik pada suhu $21^{\circ} \mathrm{C}$ atau kisaran 16--20 ${ }^{\circ} \mathrm{C}$ (AAK, 2003).

Menurut Yousef (1985), ketika suhu tinggi ternak memperlihatkan kondisi terengah-engah yang ditandai peningkatan respirasi. Pada suhu tinggi, ternak menurunkan konsumsi ransum sehingga tingkat produksi panas menurun. Turunnya konsumsi ransum berakibat pada penurunan produksi ternak. Cekaman panas diduga dapat menurunkan kadar LDL dengan cara peningkatan aktivitas enzim cholesterol $7 \alpha$ hydroxylase (CYP7) oleh suhu.

Menurut Fernandez dan West, (2005), cholesterol 7 $\alpha$-hydroxylase (CYP7) merupakan enzim yang menginisiasi konversi kolesterol menjadi asam empedu. Menurut Lehninger (1982) faktor yang mempengaruhi aktivitas enzim selain konsentrasi enzim, adalah suhu, substrat, inhibitor, dan aktivator. Hal dikarenakan setiap enzim memiliki $\mathrm{pH}$ dan sı optimum.

Menurut Sadikin (2002), jika suhu a1 bawah suhu optimum, maka aktivitas enzim akan rendah. Demikian juga dengan $\mathrm{pH}$, jika dilakukan proses di bawah $\mathrm{pH}$ optimum maka aktivitas enzim rendah. Hal ini terjadi karena struktur tiga dimensi enzim mulai berubah, sehingga substrat tidak dapat berikatan dengan sisi aktif enzim akibatnya proses katalis tidak dapat berlangsung secara sempurna. Berdasrkan hal tersebut maka dapat disimpulkan bahwa pada suhu yang tinggi akan berlangsung percepatan reaksi sehingga enzim cholesterol 7 $\alpha$-hydroxylase (CYP7) akan memproduksi lebih banyak garam empedu. cekaman panas pada broiler juga diduga dapat 
menurunkan kadar LDL melalui mekanisme hormonal.

Menurut Hillman et al., (2000), selama ayam mengalami cekaman terjadi perubahanperubahan fisiologis dan metabolisme tubuh dalam upaya mempertahankan diri dengan pengembangan sistem homeostasis yang ada, agar suhu tubuh berada pada kisaran normal. Upayaupaya tersebut berupa percepatan pengeluaran panas dengan perubahan tingkah laku dan perubahan metabolisme tubuh. Borrel (2001) menjelaskan bahwa peningkatan suhu dalam kandang pemeliharan ayam broiler pada siang hari masih dapat meningkatan sekresi hormon stres (hormon glukokortikoid).

Pada saat ternak mengalami cekaman panas maka akan ada rangsangan kepada saraf pusat dan akan diteruskan kepada hypothalamus ununtuk mensekresikan hormon $\mathrm{CRH}$, hormon ini akan menstimulus NPY untuk meningkatkan produksi hormone leptin pada jaringa adiposa, sehingga hormone leptin yang berlebih akan mengirim umpan balik negative pada saraf pusat, sehingga akan menurunkan nafsu makan.

Hal ini sesuai pendapat Zurriyati dan Dahono, (2013) yang menyatakan bahwa salah satu penyebab stres adalah perubahan suhu udara yang ekstrem yang mengakibatkan dehidrasi, nafsu makan berkurang, pertumbuhan terganggu dan badan menjadi lemah sehingga mudah terserang penyakit.

Pada saat nafsu makan berkurang maka konsumsi ransum akan berkurang, sehingga akan menurunkan pasokan lemak yang berasal dari ransum. Rendahnya pasokan lemak yang berasal dari ransum akan menurunkan kadar LDL karena kolestrol dan trigleserid yang merupakan bahan baku pembuatan kilomikron berkurang di dalam usus halus, kilomikron merupakan lipoprotein yang terkecil yang merupakan cikal bakal pembentuk LDL.

Menurut Adam, (2009), trigliserid dan kolesterol dalam usus halus akan diserap ke dalam enterosit mukosa usus halus. Trigliserid akan diserap sebagai asam lemak bebas sedang kolesterol sebagai kolesterol.

Di dalam usus halus asam lemak bebas akan diubah lagi menjadi trigliserid, sedang kolesterol akan mengalami esterifikasi menjadi kolesterol ester dan keduanya bersama dengan fosfolipid dan apolipoprotein akan memb lipoprotein yang dikenal dengan kilom Kilomikron yang terbentuk di usus ıraus kemudian akan dibawa ke hati untuk dirombak menjadi VLDL, setelah VLDL terbentuk akan dihidrolisis oleh enzim lipoprotein lipase untuk diubah menjadi IDL. IDL akan melakukan hidrolisis kembali dan akan berakhir menjadi
LDL.

Hal ini sesuai pendapat Adam (2009), trigliserid dan kolesterol yang disintesis di hati dan disekresi ke dalam sirkulasi sebagai lipoprotein VLDL. Apolipoprotein yang terkandung dalam VLDL adalah apolipoprotein B100. Dalam sirkulasi, trigliserid di VLDL akan mengalami hidrolisis oleh enzim lipoprotein lipase (LPL), dan VLDL berubah menjadi IDL yang juga akan mengalami hidrolisis dan berubah menjadi LDL. Sebagian dari VLDL, IDL, dan LDL akan mengangkut kolesterol ester kembali ke hati.

\section{KESIMPULAN DAN SARAN}

\section{Kesimpulan}

Berdasarkan penelitian yang telah dilakukan, dapat disimpulkan bahwa:

1. pemberian Nigella sativa dengan dosis 72 $\mathrm{mg} / \mathrm{kgbb}$ dalam air minum efektif dalam meningkatkan kadar HDL pada broiler jantan

2. pemberian Nigella sativa dengan dosis 144 $\mathrm{mg} / \mathrm{kgbb}$ dalam air minum efektif dalam menurunkan kadar LDL pada broiler jantan

\section{Saran}

Berdasarkan penelitian ini, saran yang perlu disampaikan yaitu :

1. perlu dilakukan penyempitan jarak dosis Nigella sativa antar perlakuan untuk mengetahui dosis pemberian Nigella sativa yang optimal dalam meningkatkan HDL dan menurunkan LDL.

2. pengambilan sampel sebaiknya dilakukan perminggu untuk mengetahui grafik perkembangan kolestrol HDL dan LDL.

\section{DAFTAR PUSTAKA}

AAK. 2003. Beternak Ayam Pedaging. Kanisius. Yogyakarta

Adam, J. 2009. Buku Ajar Ilmu Penyakit Dalam Jilid III. Penerbitan Departemen Ilmu Penyakit Dalam Fakultas Kedokteran Universitas Indonesia. Jakarta.

Al-Beitawi, N. and S.S. El-Ghousein. 2008. Effect of feeding defferent levels of Nigella sativa seed (black cumin) on performance, blood constituents and carcas characteristic of broiler chicks. J. of Poultry Science. 7(7): 715--721

Al-Majed, A. A., F. A. Al-Omar and M.N. Nagi. 2006. Neuroprotective effect of thymoquinone againts transient forebrain ischema in therathippocampus. European J. of Pharmacol.1(4): 40--47 
Azim, A.F., U. Atmomarsono dan L. D. Mahfudz. 2014. Pengaruh penambahan jintan hitam (Nigella sativa) dan vitamin c dalam ransum terhadap profil lemak ayam broiler). Animal Agriculture Journal. 3(4): 550--556

Badan Pusat Statistik. 2017. Populasi Broiler di Indonesia. www. bps.go.id diakses pada 18 Oktober 2019

Bambang, H., I. Irawan., dan N. Iriyanti. 2005. Pengaruh asam lemak dan serat kasar yang berbeda dalam ransum broiler terhadap kadar HDL dan LDL serum darah. $J$. Animal Production. 7(1) : 27--33

Basmacioglu, H. and M. Ergul. 2005. Research on the factor affecting cholesterol content and some other characteristics of eggs in laying hens. J. Vet. Anim. Sci.29(9): 157-164

Fernandez.M.L. and K.L. West. 2005. Mechanisms by which dietary fatty acids modulate plasma lipids. $J$ Nutr.1(35): 2075-2078

Ganong,W.F. 1983. Fisiologi Kedokteran diterjemahkan oleh M. Djauhari Widjajakusumah dan A. Tanzil.Penerbit Buku Kedokteran EGC. Jakarta

Guyton, A.C. dan J.E. Hall. 1997. Buku Ajar Fisiologi Kedokteran. Edisi ke-9. Diterjemahkan oleh: Irawati Setiawan. EGC. Jakarta

Hillman, P.E., N. R. Scot., and V. Tienhoven. 2000. Physiological, responses and adaptations to hot and cold environments. J. Poultry. 3(1):71--72

Krisnatuti, D dan Rina. 1999. Perencanaan Menu Bagi Penderita Jantung Koroner. Trubus Agriwidya. Jakarta

Lehninger, A. 1982. Dasar dasar Biokimia. Diterjemahkan oleh: Dr. Ir. Maggy Thenawidjaja. Penerbit Erlangga. Jakarta.

Lembaga Ilmu Pengetahuan Indonesia (LIPI). 2009. Kolesterol Pangan dan Kesehatan. UPT-Balai Informasi Teknologi. Jakarta.

Manoppo, M., R. A., R. Sugihartuti, T. S. Adikara dan Y. Dhamayanti. 2007. Pengaruh pemberian crude chrorella terhadap total kolesterol darah ayam broiler. Fakultas Kedokteran Hewan. Universitas Airlangga. Surabaya

Meliandasari, D., B. Dwiloka dan E. Suprijatna. 2014. Profil perlemakan darah ayam broiler yang diberi pakan tepung daun kayambang (Salvinia molesta). J. IlmuIlmu Peternakan 2 (1):45--55.

Martin, D.W., P. A. Mayes, V. W. Rodwell dan D. K. Graner. 1992. Biokimia Harper (Harper's Review of Biochenistry). Edisi 6. EGCP Buku Kedokteran Jakarta.
Michael., L. Bishop, E.P. Fody., E. Larry., Schoeff. 2013. Clinical Chemistry Seven Edition: Principles, Techniques, and Correlations. Copyright Philadelphia, PA 19103 USA.

Moeliandari, F dan A. Wijaya. 2002. Metabolisme dan mekanisme anti-aterosklerotik dari HDL, suatu pandangan baru. http:/www.Prodia.co.id/files/FD/f diag.4.2002.pdf. diakses pada 27 Februari 2020

Murray, R.K., D.K. Granner., P.A. Mayes., and V.W Rodwell,.1996. Biokimia Harper. Diterjemahkan oleh : FKUI. Penerbit Buku Kedokteran EGC. Jakarta.

Murwani. 2010. Broiler Modern. CV. Widya Karya. Semarang

Nogrady T. 1992. Kimia medisinal: pendekatan secara biokimia. Penerbit ITB. Bandung

Rawayulis, R. 2008. 17 Alternatif Untuk Langsing. Penerbit Plus. Jakarta

Rasyaf. 2011. Panduan Beternak Ayam Pedaging. Edisi Ke-15. Kanisius. Yogyakarta.

Rolfes, S. R., K. Pinna, and E. Whitney. 2006. Understanding Normal and Clinical Nutrition. Belmont. Thompson Wadsworth. USA

Sadikin, M. 2002. Biokimia Enzim. Widya Medika. Jakarta

Setiawati, T., U. Atmomarsono dan B. Dwiloka. 2014. Pengaruh pemberian tepung daun kayambang (Salvinia molesta) terhadap

Sugito. Fakhrurrazi, dan M. Isa. 2011. Efek pemberian ekstrak Jaloh dikombinasi dengan probiotik dan kromium terhadap profil hematologi dan titer antibodi vaksin ND pada ayam broiler yang mengalami stres panas. Jurnal Agripet. 11(2.): 8--15

Sunita, A. 2004. Prinsip Dasar Ilmu Gizi. Gramedia. Jakarta

Suprijatna, E.U.A. dan R, Kartasudjana. 2005. Ilmu Dasar Ternak Unggas. Penebar Swadaya, Jakarta

Suryaatmadja, M dan E. Silman. 2006. Diagnosa Laboratorium Kelainan Lemak Darah. CDK 30: 14-6

Stryer, L. 1996. Biokimia. Terjemahan FKUI. Penerbit Buku Kedokteran EGC. Jakarta

Sturkie. 2000. Avian Physiology. Spinger Verlag Press. New York. USA

Yousef, M. K. 1985. Stress Physiology in Livestock Basic Principles. CRC Press Inc. Boca Raton. Florida. 